\title{
Saline-induced changes of epicuticular waxy layer on the Puccinellia tenuiflora and Oryza sativa leave surfaces
}

\author{
Chunxue Yang ${ }^{1}$, Shurong Ma ${ }^{1}$, Imshik Lee ${ }^{1,2}$, Jaineung Kim³ and Shenkui Liü ${ }^{1 *}$
}

\begin{abstract}
Background: The epicuticular waxy layer of plant leaves enhances the extreme environmental stress tolerance. However, the relationship between waxy layer and saline tolerance was not established well. The epicuticular waxy layer of rice (Oryza sativa L.) was studied under the $\mathrm{NaHCO}_{3}$ stresses. In addition, strong saline tolerance Puccinellia tenuiflora was chosen for comparative studies.

Results: Scanning electron microscope (SEM) images showed that there were significant changes in waxy morphologies of the rice epicuticular surfaces, while no remarkable changes in those of $P$. tenuiflora epicuticular surfaces. The $\mathrm{NaHCO}_{3}$-induced morphological changes of the rice epicuticular surfaces appeared as enlarged silica cells, swollen corns-shapes and leaked salt columns under high stress. Energy dispersive X-ray (EDX) spectroscopic profiles supported that the changes were caused by significant increment and localization of $\left[\mathrm{Na}^{+}\right]$and $\left[\mathrm{Cl}^{-}\right]$in the shoot. Atomic absorption spectra showed that $\left[\mathrm{Na}^{+}\right]_{\text {shoot }} /\left[\mathrm{Na}^{+}\right]_{\text {root }}$ for $P$. tenuiflora maintained stable as the saline stress increased, but that for rice increased significantly.
\end{abstract}

Conclusion: In rice, $\mathrm{NaHCO}_{3}$ stress induced localization and accumulation of $\left[\mathrm{Na}^{+}\right]$and $\left[\mathrm{Cl}^{-}\right]$appeared as the enlarged silica cells (MSC), the swollen corns (S-C), and the leaked columns (C), while no significant changes in P. tenuiflora.

Keywords: Saline tolerance, Morphology, Wax crystal, Element analysis, $\mathrm{Na}^{+}$localization

\section{Background}

Soil salination has become an important factor that restricts agricultural development across the globe. Saline soil takes up $37 \%$ of the world's arable land [1]. Saline regions in China are mostly composed of $\mathrm{Na}_{2} \mathrm{CO}_{3}$ and $\mathrm{NaHCO}_{3}$. Up-to-date researchers have focused salt tolerance study on $\mathrm{NaCl}$, but rare on alkali salt. The threats posed by alkali salt are much more complex and destructive to the ecosystem than by neutral salt [2].

The waxy layer that covers over plant surfaces plays an important role in natural package, which serves as the first barrier to protect plants against threats from the external environment $[2,3]$. The waxy layer helps protect plants against non-biological stress such as non-stomatal water

\footnotetext{
* Correspondence: shenkuiliu@nefu.edu.cn

'Key Laboratory of Saline-alkali Vegetation Ecology Restoration in Oil Field (SAVER), Ministry of Education, Alkali Soil Natural Environmental Science Center (ASNESC), Northeast Forestry University, Harbin 150040, China Full list of author information is available at the end of the article
}

loss, insect intrusion [4], bacterial invasion, ultraviolet radiation and frost [5]. This natural wax mechanism brings new insight not only for environmental and agricultural applications, but also for the industrial application in biomimetics-package. The waxy surface varies from plant to plant [6-8]. Content of plant waxy is determined not only genetically, but also influenced by the environment. The environmental factors have an impact on the biochemical process of waxy synthesis. Correlation between epidermal waxy deposits and drought tolerance has been found in various plants $[8,9]$. However, there was rare research on the relationship between plants' waxy layer and their saline tolerance [10].

P. tenuiflora is a perennial grass of the Gramineae family and has extremely strong saline tolerance, which is used as a pioneer plant in the improvement of saline soils. The waxy surfaces of the $p$. tenuiflora leaves have always been a controversial issue with regard to a saltsecreting structure [10]. The excess salt in P. tenuiflora 
could be discharged through the formation of the waxy layer. However, it is unclear how exactly do the changes of the waxy layer respond to different degrees of saline stress.

Rice (O. sativa L.) is one of the most widely consumed foods as well as the second-highest production of food over the world. Rice has a medium saline tolerance. The epicuticular surface of rice shoots is composed of epidermis cell, stomatal guard cell, trichome, and wart-like protuberance (silicon cell) with crystalline wax layers. There is a salt tolerance wild rice but no cultivated rice that has the discharge of the excessive salts [11].

In this work, we selected P. tenuiflora and rice, for the further studies in dynamic characteristics of the epicuticular waxy formations in terms of different exposures of $\mathrm{NaHCO}_{3}$ stress. The changes in the waxy ornamentation of epicuticular surface of $P$. tenuiflora and rice leaves under $\mathrm{NaHCO}_{3}$ stress were visualized by using environmental scanning electron microscope (ESEM) and their chemical composition were analyzed by X-ray diffraction (XRD) analysis. The relationship between epicuticular waxy layer and saline tolerance was explored based on the observations.

\section{Results}

\section{Morphologies of the epicuticular surfaces}

Figure 1 showed the typical ESEM images of the epicuticular surfaces of rice and P. tenuiflora leaves. The epicuticular surface of rice leaves (Fig. 1a and b) contained epidermis cell (EC), stomatal guard cell (GC), stomatal subsidiary cell ( $\mathrm{SbC})$, trichome (TC), and wart-like protuberance (silica cell, SC). Crystalline wax covered over the epicuticular surfaces. Wax crystals appeared as randomly distributed crystals over the epicuticular surfaces (Fig. 1b). The wax crystals showed no specific orientation, and their planes were standing with acute angles to the epicuticular surface. The random orientation of small-sized crystalline waxes formed the micro-networks. The heights of platelet wax crystals were less than $0.2 \mu \mathrm{m}$. There was no noticeable difference of crystalline wax layers on EC, GC, SbC, and SCs, but no on TC.

Figure $1 c$ and $d$ showed the similar wax crystals on the epicuticular surface of the $P$. tenuiflora leaves. It seemed that there were two different sized crystals in the waxy networks (Fig. 1d). Smaller crystals formed more dense networks within the networks formed by bigger crystals. There was no distinction of waxy morphology between

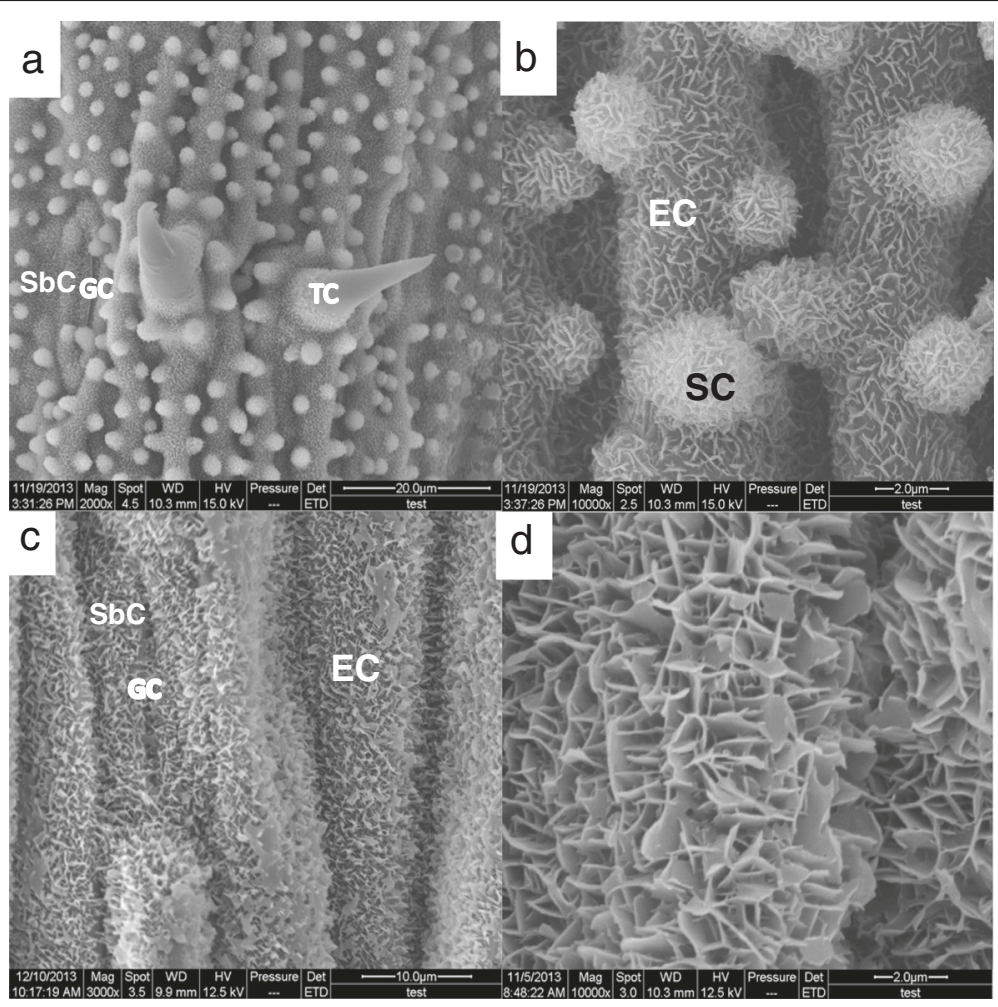

Fig. 1 ESEM visualization of the epicuticular rice surfaces under the normal conditions. a Rice leaf epicuticular surface containing epidermis (EC), guard cell (GC), silica cell (SC), subsidiary cell (SbC), and trichome (TC). Bar $=20 \mu \mathrm{m}$. b Magnified ESEM image of rice leaf to visualize the crystalline wax platelet networks on the epicuticular surfaces. Bar $=2 \mu \mathrm{m}$. $\mathbf{c}$ P. tenuiflora leaf epidermis. Bar $=10 \mu \mathrm{m}$. $\mathbf{d}$ Magnified ESEM image of $P$. tenuiflora leaf surface. Bar $=2 \mu \mathrm{m}$ 
on EC, GC, and SbC. There were no SC and TC on the $P$. tenuiflora leaves. The density of the wax crystal networks in $P$. tenuiflora was higher than that in rice.

\section{$\mathrm{NaHCO}_{3}$ stress induced changes of rice epicuticular surfaces}

As $\mathrm{NaHCO}_{3}$ stress increased for the rice samples, the epicuticular morphologies changed (Fig. 2). Figure $2 b$ showed that wart-like protuberance silica cells merged and enlarged to be the big protuberances (MSC). The distribution density of wax crystal networks deceased and disappeared on the apex surfaces of the MSC. At $100 \mathrm{mM} \mathrm{NaHCO}$ with 7 days exposure, leaked columns $(C)$ and/or swollen cornshapes (S-Cs) appeared on the surface (Fig. 2c). Interestingly, wax crystals remained on the surfaces of the S-Cs. Diameter of the leaked columns was $2 \sim 5 \mu \mathrm{m}$, while the size of the swollen corn was bigger than $10 \mu \mathrm{m}$. Cracked side view of the S-Cs revealed the cubic crystals as marked arrow in Fig. 2d, indicating $\mathrm{NaCl}$ crystals. There were also the solidified particles underneath of the cell wall as marked number 6 on Fig. 2d.

\section{EDX element analysis of the epicuticular surface of rice leaves}

EDX microanalysis spectroscopies were obtained from the different spots over the epicuticular surfaces as marked numbers in Fig. 2. For the controlled rice leave surfaces, there were no significant difference among the EDX spectroscopies obtained from SbC, EC and SC. C and $\mathrm{O}$ elements (Fig. 3a and $\mathrm{b}$ ) were dominated. Traces of other elements including gold were also detected. Relatively high gold peak came from the gold coating. The level of silicon accumulation was low on both epidermal region and silica cells. For the $\mathrm{NaHCO}_{3}$ exposed rice, there were significant changes in $\mathrm{Na}$ and $\mathrm{Cl}$ counts at the points on the merged and enlarged silica cells (MSC) (Fig. 3c), the swollen corn shapes (S-C) (Fig. 3d) and the leaked columns (C) (Fig. 3e). Weight \%s of $\mathrm{Na}$ and $\mathrm{Cl}$ on

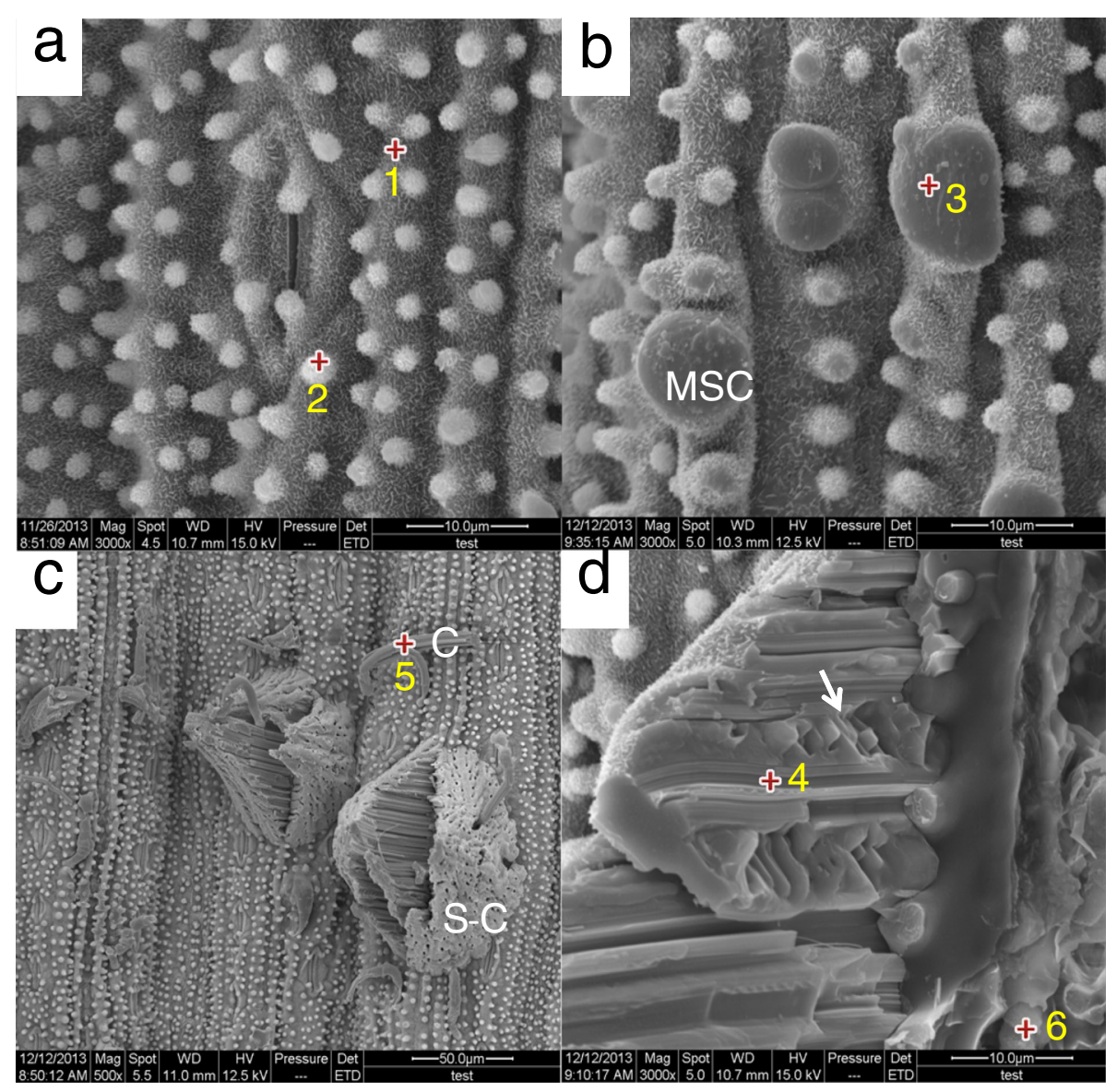

Fig. 2 ESEM photographs of rice epicuticular surfaces; (a) under no $\mathrm{NaHCO}_{3}$ stress. Bar $=10 \mu \mathrm{m}$. b Under $100 \mathrm{mM} \mathrm{NaHCO}$ for 5 days exposure. Bar $=10 \mu \mathrm{m}$. Merged/enlarged silica cells (MSCs) were newly formed. c Under $100 \mathrm{mM} \mathrm{NaHCO}_{3}$ stress for 7 days exposure. Bar $=50 \mu \mathrm{m}$. Swollen corn-shapes (S-Cs) and columns (Cs) appeared. d Magnified ESEM image of cross-section of a swollen corn-shape Under $200 \mathrm{mM} \mathrm{NaHCO}_{3}$ stress for 5 days exposure. Bar $=10 \mu \mathrm{m}$. S-C. Cubic crystals appeared as marked arrow. The marked numbers are the spots for EDX microanalysis 


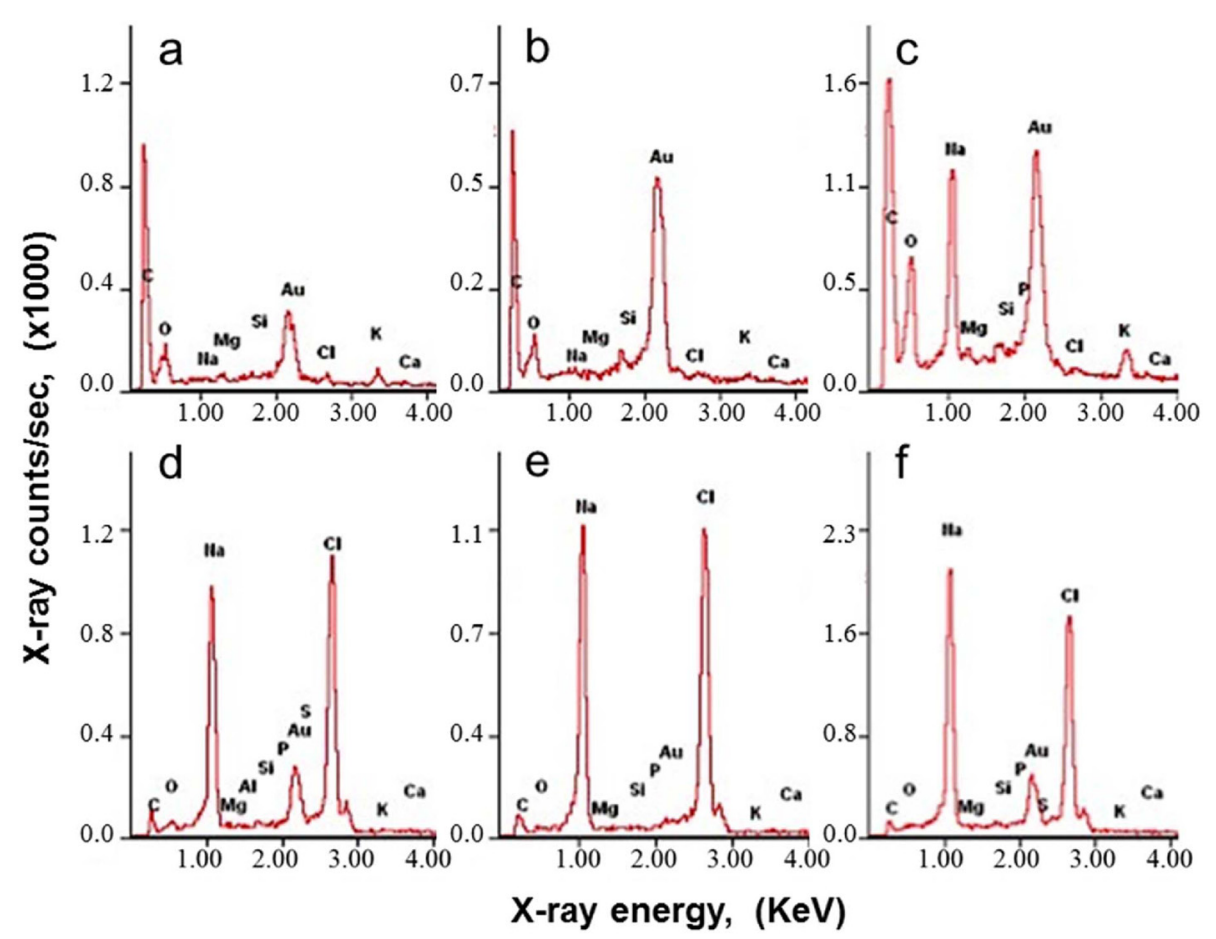

Fig. 3 EDX microanalysis spectra of rice leaves. The spectra obtained from; (a) EC under no $\mathrm{NaHCO}_{3}$ stress (\#1 spot in Fig. 2a), (b) SC under no $\mathrm{NaHCO}_{3}$ stress (\#2 spot in Fig. 2a), (c) MSC under $100 \mathrm{mM} \mathrm{NaHCO}_{3}$ for 5 days exposure (\#3 spot in Fig. 2b), (d) S-C under 200 mM NaHCO for 5 days exposure (\#4 spot in Fig. 2d), (e) $\mathrm{C}$ under $100 \mathrm{mM} \mathrm{NaHCO}_{3}$ for 7 days exposure (\#5 spot in Fig. 2c), and (f) The solidified particles underneath of the cell wall under $200 \mathrm{mM} \mathrm{NaHCO}_{3}$ for 5 days exposure (\#6 spot in Fig. 2d)

MSC were counted $12.5 \%$ and $0.3 \%$, respectively. EDX spectra from the localized swollen corn surfaces showed that concentrations of $\mathrm{Na}$ and $\mathrm{Cl}$ were $20 \sim 30$ time higher than those form the normal controlled surfaces. The particles underneath cell wall also showed high counts of $\mathrm{Na}$ and $\mathrm{Cl}$ (Fig. 3f). The cubic crystals on cross-section surface of the swollen corn appeared, indicating $\mathrm{NaCl}$ crystal. At the higher saline stress, condensed $\mathrm{Na}$ and $\mathrm{Cl}$ were leaked trough the ruptured surfaces to form the $\mathrm{NaCl}$ columns. There was more excessive $\mathrm{Cl}^{-}$than $\mathrm{Na}^{+}$on the swollen corns, while excessive $\mathrm{Na}^{+}$than $\mathrm{Cl}^{-}$on the leaked columns.

We have scanned over the surfaces to visualize the morphology depended $\mathrm{Na}^{+}$distribution by using ESEM. Figure 4 showed $\mathrm{Na}$ and $\mathrm{K}$ contour maps over the surfaces after 7 and 9 days exposure to100 $\mathrm{mM} \mathrm{NaHCO}_{3}$. Compartmented $\mathrm{Na}^{+}$was found underneath the epicuticular surfaces, but no $\mathrm{K}^{+}$. The surface morphologies over the high $\mathrm{Na}^{+}$accumulations were different from those over the control surfaces. It seemed that the degree of $\mathrm{Na}^{+}$was associated with the morphological changes of the epicuticular surface.

\section{Absorption comparison of cytosolic $\mathrm{Na}^{+}$and $\mathrm{K}^{+}$in rice and $p$. tenuiflora}

Plant usually balances at low cytosolic $\left[\mathrm{Na}^{+}\right]$, and a cytosolic $\left[\mathrm{K}^{+}\right] /\left[\mathrm{Na}^{+}\right]>1[12]$. Figure 5 showed that $\mathrm{Na}^{+}$influx from the high external $\left[\mathrm{NaHCO}_{3}\right]$ altered the $\left[\mathrm{K}^{+}\right] /\left[\mathrm{Na}^{+}\right]$ in the rice. $\mathrm{Na}^{+}$distribution ratio of shoot to root for rice also increased significantly from $0 \mathrm{mM}$ to $150 \mathrm{mM}$ $\mathrm{NaHCO}_{3}$ stress, appearing as $\left[\mathrm{Na}^{+}\right]_{\text {shoot }} /\left[\mathrm{Na}^{+}\right]_{\text {root }}>1$ (Fig. 5a). It seems the absorbed $\mathrm{Na}^{+}$ions from root were transported to the shoot. Consequently, the $\left[\mathrm{K}^{+}\right] /\left[\mathrm{Na}^{+}\right] \mathrm{ra}-$ tios in rice shoots decreased gradually lower than 1 (Fig. 5b). Transported $\mathrm{Na}^{+}$ions were accumulated to be toxic effects in rice shoot. At the $200 \mathrm{mM} \mathrm{NaHCO}_{3}$ stress, $\left[\mathrm{Na}^{+}\right]_{\text {shoot }}$ dropped dramatically (\# marked in Fig. $5 \mathrm{a}$ and b). This $\left[\mathrm{Na}^{+}\right]$decrement may be caused from a dyefunctioned rice (yellowish colored shoot) due to high toxicity. Localized $\mathrm{NaCl}$ swollen corn shapes and columns formed by rupturing and/or leaking highly accumulated $\mathrm{NaCl}$ were correlated to decreased cytosolic $\left[\mathrm{Na}^{+}\right]$at extremely high $\mathrm{NaHCO}_{3}$ stress.

For $P$. tenuiflora, $\mathrm{Na}^{+}$concentrations of both root $\left(\left[\mathrm{Na}^{+}\right]_{\text {root }}\right)$ and shoot $\left(\left[\mathrm{Na}^{+}\right]_{\text {shoot }}\right)$ were always balanced well at a very low level. This stable $\left[\mathrm{Na}^{+}\right]_{\text {root }} /\left[\mathrm{Na}^{+}\right]_{\text {shoot }}$ indicated that the external saline stress barely affected $P$. tenuiflora, which was different from those for rice. Figure $5 \mathrm{~b}$ showed that ratio of $\left[\mathrm{K}^{+}\right] /\left[\mathrm{Na}^{+}\right]$decreased for both $P$. tenuiflora and rice, but for $P$. tenuiflora, $\left[\mathrm{K}^{+}\right]$ was twice higher than $\left[\mathrm{Na}^{+}\right]$as $\mathrm{NaHCO}_{3}$ stress increased, while $\left[\mathrm{K}^{+}\right]$became almost 5 times lower than $\left[\mathrm{Na}^{+}\right]$for rice. 


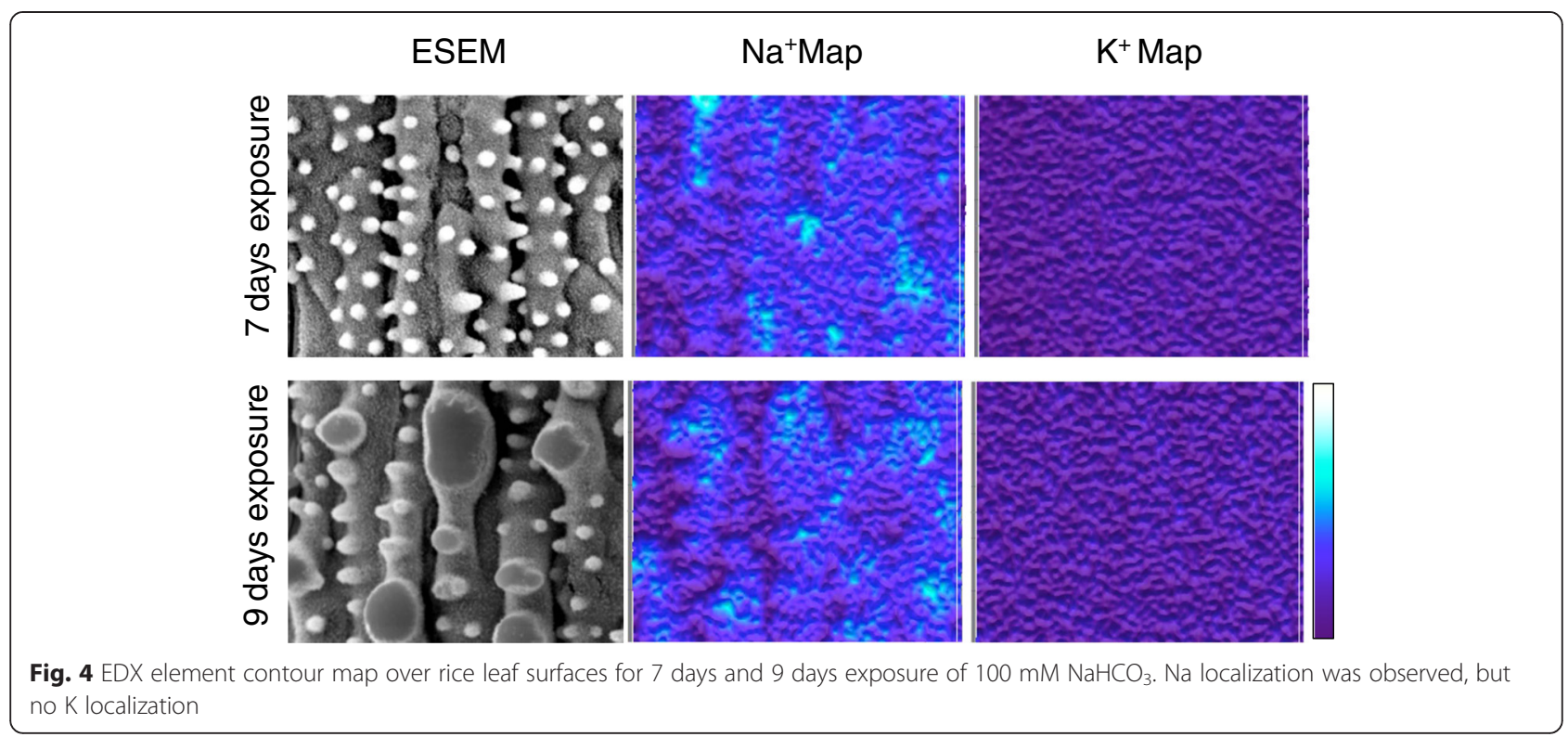

\section{Surface morphology and EDX profiles for $P$. tenuiflora}

Figure 6 showed the epicuticular morphologies of $P$. tenuiflora with EXD characterization. Interestingly, epicuticular surface morphology of $P$. tenuiflora had no remarkable changes with experiencing the $\mathrm{NaHCO}_{3}$ stress (Fig. 6). Morphology of waxy crystal network on the $P$. tenuiflora epidermis surfaces was similar as that on the controlled rice leave surfaces. Even at high $\mathrm{NaHCO}_{3}$ stress, $150 \mathrm{mM}$ for 21 days exposure, the wax and surface morphologies had no remarkable changes, EDX profiles also showed no remarkable changes of the element concentrations either, including $\mathrm{Na}^{+}$and $\mathrm{K}^{+}$.

\section{Discussion}

The waxy layer on the leaf surfaces prevents both molecular uptake and efflux. For both rice and P. tenuiflora, crystalline wax distributed randomly to form the micronetworks over the epicuticular surfaces. There was no distinction in the structure and density of wax crystal networks between different types of epicuticular cells, but no wax crystal networked coverage on the TC surfaces (Fig. 1a).

As both rice and $P$. tenuiflora exposed to $\mathrm{NaHCO}_{3}$ stress, no noticeable changes of the crystalline wax networks were observed. It seemed that the external $\mathrm{NaHCO}_{3}$ stress did not alter the wax synthesis metabolisms. However, surface morphologies of rice leaves had significant changes as $\mathrm{Na}^{+}$ localization increased. The surface deformation might be caused mainly by the $\mathrm{Na}^{+}$accumulation under $\mathrm{NaHCO}_{3}$ stress. Surface deformations appeared as protruded surface bands and MSC, $\mathrm{C}$ and S-C for rice. The observed $\mathrm{C}$ and $\mathrm{S}-\mathrm{C}$ on the disrupted-waxy surfaces of rice epidermis were composed mainly by $\mathrm{NaCl}$. In addition, the excessive $\mathrm{Na}^{+}$ could be toxic to plant metabolism affecting its development and growth.

Under the $\mathrm{NaHCO}_{3}$ stress, atomic absorption spectra showed no noticeable increment of $\left[\mathrm{Na}^{+}\right]_{\text {root }}$ for both rice and $P$. tenuiflora. It seemed that root had the capability to
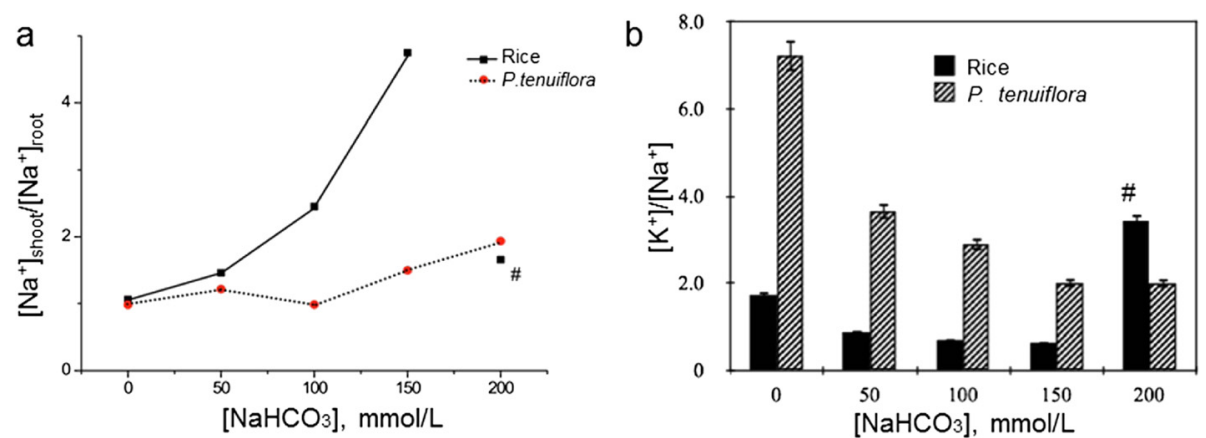

Fig. 5 Atomic absorption spectroscopy under different $\mathrm{NaHCO}_{3}$ stress; (a) the ratio distribution of the absorbed $\mathrm{Na}^{+}$ions from root to shoot, $\left[\mathrm{Na}^{+}\right]_{\text {shoot }} /\left[\mathrm{Na}^{+}\right]_{\text {root }}$ of rice and $P$. tenuiflora. $\mathbf{b}\left[\mathrm{K}^{+}\right] /\left[\mathrm{Na}^{+}\right]$ratio distribution of rice and $P$. tenuiflora shoot. (\#; unusual data by $\mathrm{Na}^{+}$ toxicity in shoot) 


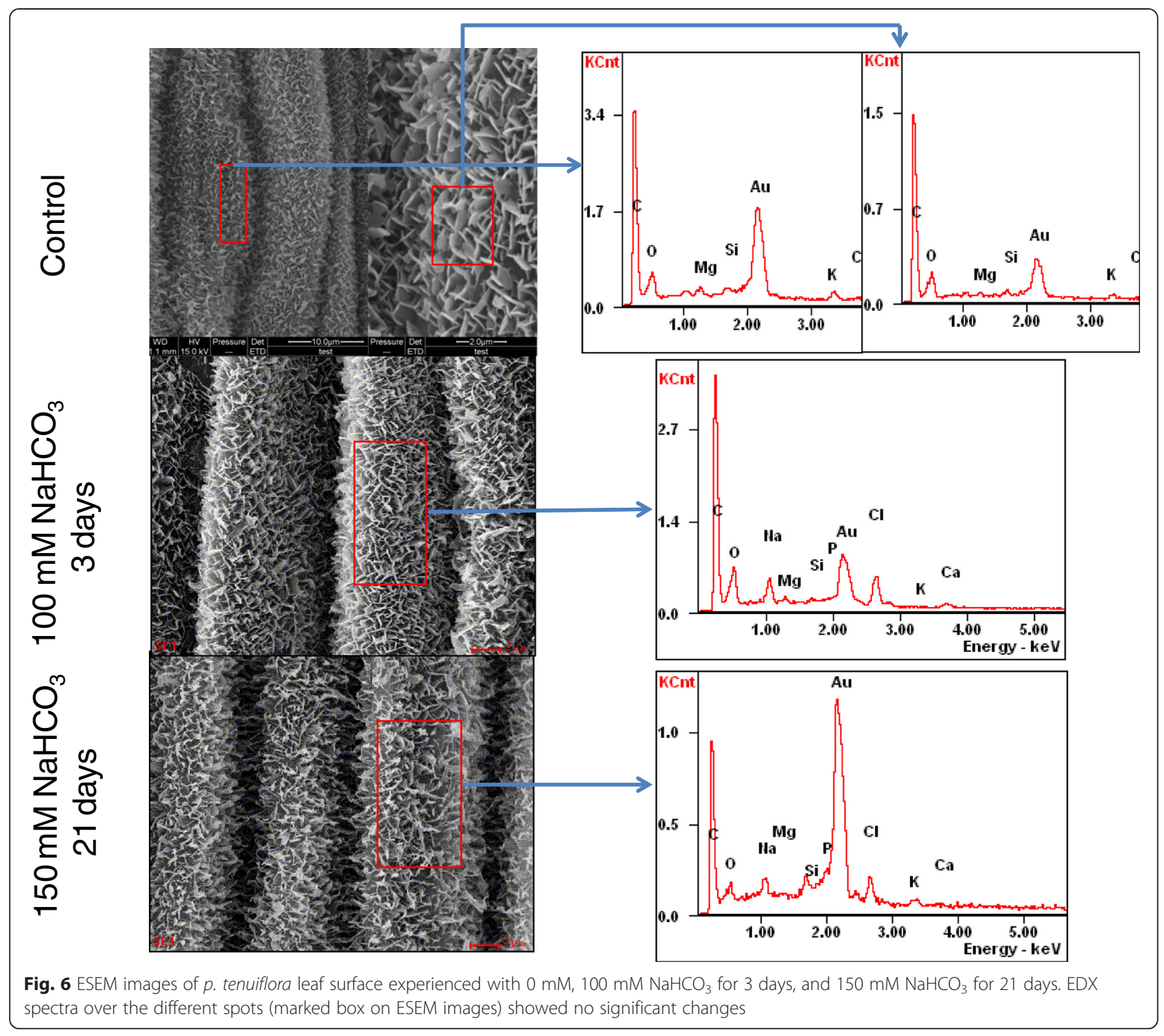

maintain the cytosolic hemostasis at low $\left[\mathrm{Na}^{+}\right]_{\text {root }} /\left[\mathrm{K}^{+}\right]_{\text {root }}$. However, for rice, $\left[\mathrm{Na}^{+}\right]_{\text {shoot }}$ increased as the external salt stress increased in terms of exposure time and concentration of $\mathrm{NaHCO}_{3}$. The absorbed $\mathrm{Na}^{+}$ions from root seemed to be transported to shoot and to be accumulated in the tissue cells of shoot. Excessive $\mathrm{Na}^{+}$in the rice shoot caused the increment of $\left[\mathrm{Na}^{+}\right]_{\text {shoot }} /\left[\mathrm{K}^{+}\right]_{\text {shoot }}$ which was toxic to its growth. Consequently, dysfunction of rice under the $\mathrm{NaHCO}_{3}$ stress began not from root but from the shoot. In general, high $\left[\mathrm{Na}^{+}\right]_{\text {shoot }}$ in halophytes imply compartmentation into the vacuole to maintain the ion homeostasis. Our results showed the compartmented $\mathrm{Na}^{+}$ over epicuticular surfaces of $\mathrm{NaHCO}_{3}$ experienced rice, but no $\mathrm{K}^{+}$compartmentation (Fig. 4). However it was not clear whether the compartmentations were in the vacuole.

EDX element analysis showed no homogeneous $\left[\mathrm{Na}^{+}\right]$ enhancement over the epicuticular surface of rice leave as $\mathrm{NaHCO}_{3}$ stress increased. Initially wart-like protuberance silica cells were enlarged and merged to the big protuberance silica cell (MSC) (Fig. 2b). These manners of morphological changes are very similar to those under the silicon treatments due to the accumulation of silicon $[13,14]$. Silicon is predominantly deposited in wart-like protuberance silica cells of the epidermis. Our X-ray microanalysis spectra showed that $\mathrm{Na}$ presented highly on the enlarged/merged silica cells (Fig. 3c) with low Na X-ray counts around stomatal guard cell areas. It seemed that excessive $\mathrm{Na}$ accumulated in silica cells as a similar manner of $\mathrm{Si}$ accumulation.

Further enhanced $\mathrm{NaHCO}_{3}$ stress induced the swollen corn-shaped (S-C) dumps and/or columns (C) on the epicuticular surface (Fig. 2c). EDX element spectra showed that those localized morphologies contained 
mostly $\mathrm{NaCl}$. The cubic crystals appeared on the crosssection surface were confirmed to be $\mathrm{NaCl}$ crystal (arrow mark in Fig. 2d). Interestingly, the surface of swollen $(\mathrm{S}-\mathrm{C}) \mathrm{NaCl}$ localization was covered with the wax crystals networks, but that of $\mathrm{NaCl}$ column (C) was not. It suggested that the swollen localizations were formed slowly without disrupting the wax crystalline networks. The holes of the surface of this swollen localization indicated the remaining silica cells without swelling. However, the $\mathrm{NaCl}$ columns were formed by $\mathrm{NaCl}$ leakage from the silica cells. Highly accumulated $\mathrm{NaCl}$ was also observed underneath of the cell wall where the swollen localizations were found (Figs. $2 \mathrm{~d}$ and 3f). The localization or secretion of highly $\mathrm{NaCl}$ accumulation on the epicuticular surfaces may be corresponding to the sudden recovery $\left[\mathrm{Na}^{+}\right]_{\text {shoot }} /\left[\mathrm{K}^{+}\right]_{\text {shoot }}$ at $200 \mathrm{mM}$ $\mathrm{NaHCO}_{3}$ as shown in Fig. 5 .

$\mathrm{Na}$ accumulation dominated in the enlarged silica cells, while in the swollen and column, $\mathrm{Na}$ and $\mathrm{Cl}$ elements dominated. There were noticeable difference in the element composition, $\mathrm{Na}>\mathrm{Cl}$ for the leaked $\mathrm{NaCl}$ columns and $\mathrm{Na}<\mathrm{Cl}$ for the swollen $\mathrm{NaCl}$. This difference may be correlated to the different manner of $\mathrm{NaCl}$ secretion. The portion of free $\mathrm{Na}^{+}$was accumulated in intra-cuticle cell wall, and the $\mathrm{NaCl}$ crystals were excreted in the form of column and swollen dump. It seemed that the $\mathrm{NaCl}$ secretion occurred after dysfunction. It would be a great challenge to trigger the $\mathrm{NaCl}$ secretion before dysfunction to enhance the salt tolerance on rice leaves.

The results obtained from atomic absorption spectroscopy showed that highly concentrated $\mathrm{Na}^{+}$ions on the rice leave might be transported from root to shoot. For rice, the transported $\mathrm{Na}^{+}$ions were accumulated in shoot appearing as the increment of $\left[\mathrm{Na}^{+}\right]_{\text {shoot }}$, $\left[\mathrm{Na}^{+}\right]_{\text {shoot }} /\left[\mathrm{Na}^{+}\right]_{\text {root }}>1$. For P. tenuiflora, we did not observe the secreted $\mathrm{Na}^{+}$ions on the surface of its leaf, but there might be some mechanisms to maintain the ionic homeostasis, $\left[\mathrm{Na}^{+}\right]_{\text {shoot }} /\left[\mathrm{K}^{+}\right]_{\text {shoot }}<1$.

\section{Conclusions}

With the increase in $\mathrm{NaHCO}_{3}$ stress concentrate and time, there were no significant changes on the morphology of the waxy crystal networks for both rice and $P$. tenuiflora epidermis, however the epicuticular morphology of rice leave altered dramatically. MSC, S-C and C appeared as $\mathrm{NaHCO}_{3}$ stress increased. These new morphologies were correlated with the $\mathrm{Na}^{+}$and $\mathrm{Cl}^{-}$ accumulations.

\section{Methods}

\section{Plant cultivation and treatment}

P. tenuiflora and O. sativa L. cv. (Nipponbare rice) were cultivated in hydroponics with a temperature of $25 \sim 28{ }^{\circ} \mathrm{C}$, light exposure of $6000 \mathrm{~lx}$, optical cycle of 16/8 h (day/night), and relative humidity of $60 \%$. Water was changed every 5 days. During the process of cultivation, 1/4 Hoagland was used for 2 to 3 days and for the rest of the time distilled water was used.

Ninety $P$. tenuiflora and rice seedlings of trefoil stage were selected and divided randomly into three different groups, 30 for each. The roots were washed with distilled water. The seedlings were then placed under $0 \mathrm{mM}, 50 \mathrm{mM}, 100 \mathrm{mM}, 150 \mathrm{mM}$ and $200 \mathrm{mM} \mathrm{NaHCO} 3$ stress for 1, 3, 5, 7, 9 and 21 days for P. tenuiflora, and under $0 \mathrm{mM}, 50 \mathrm{mM}, 100 \mathrm{mM}$, $150 \mathrm{mM}$ and $200 \mathrm{mM} \mathrm{NaHCO}$ stress for 1, 3, 5, 7, and 9 days for rice, respectively.

\section{ESEM and EDX observations}

The middle sections of the second true leaves of $P$. tenuiflora and rice seedlings were taken randomly in the treatment group and the control group. They were cut into $3 \sim 5 \mathrm{~mm}$ segments, quickly fixed in $3 \%$ glutaricdialdehyde. The dehydrated samples with a vacuum dryer were coated with grain-size gold particles by using sputter coater (SCD005, Bal-Tec GmbH, Germany). The epicuticular surfaces of rice leaves were then visualized with an environmental scanning electron microscopy (ESEM, Quanta-200, Fei Co., USA). Wax composition and epicuticular chemical composition were recorded by EDX during ESEM imaging. X-rays were collected with a detector at the takeoff angle of $30^{\circ}$.

\section{$\left[\mathrm{Na}^{+}\right]$and $\left[\mathrm{K}^{+}\right]$measurements}

Saline stress was applied under $50 \mathrm{mM}, 100 \mathrm{mM}$, $150 \mathrm{mM}$ and $200 \mathrm{mM} \mathrm{NaHCO}$. Sample groups were cultivated for 5 days, and the sample materials were removed from the stress solution, washed two times with distilled water to remove surface salt ions. The prepared shoot and root were placed on dry filter paper for absorbing moisture and dried in an oven at $105{ }^{\circ} \mathrm{C}$ for $10 \mathrm{~min}$. The dried samples were grounded and digested in the $10 \mathrm{ml}$ nitric acid and $1 \mathrm{ml}$ perchloric acid solution. Using 220FS atomic absorption spectrophotometer (Varian, USA), $\left[\mathrm{Na}^{+}\right]$of root and shoot were measured.

\section{Competing interests}

The authors declare that they have no competing interests.

\section{Authors' contributions}

Conceived and designed the experiments: CY IL SL. Performed the experiments: CY SM. Analyzed the data: CY IL JK SL. Contributed reagents/materials/analysis tools: SL. Contributed to the writing of the manuscript: CY IL JK SL. All authors read and approved the final manuscript.

\section{Acknowledgements}

This work was supported by a program from the National High Technology Research and Development Program of China (2013AA102701-7) to Shenkui Liu, two grants from the Fundamental Research Funds for the Central Universities (2572015CA22) and Heilongjiang Postdoctoral Grant (LBH-Z11250) 
to Chunxue Yang. We thank Hui Zhang, Qiuhong Wang, Wei Shi and Hua Liu for providing suggestion and help.

\section{Author details}

'Key Laboratory of Saline-alkali Vegetation Ecology Restoration in Oil Field (SAVER), Ministry of Education, Alkali Soil Natural Environmental Science Center (ASNESC), Northeast Forestry University, Harbin 150040, China. ${ }^{2}$ Institute of Physics, Nankai University, Tianjin 130071, China. ${ }^{3}$ Deparment of Packaging Engineering, Yonsei University, Wonju, Kangwon-do 220-710, South Korea.

Received: 24 September 2014 Accepted: 22 June 2015

Published online: 01 July 2015

\section{References}

1. Szabolcs I. Salt-affected soil. Boca Raton, Fla: CRC Press, Inc.; 1989. p. 274.

2. Broun $P$, Poindexter $P$, Osborne $E$, Jiang CA, Maarten C. WIN1, a transcriptional activator of epidermal wax accumulation in Arabidopsis. Proc Natl Acad Sci U S A. 2004;101:4706-11.

3. Pighin JA, Zheng HQ, Balakshin $L$, Goodman IP, Western TL, Jetter R, et al. Plant cuticular lipid export requires an $A B C$ transporter. Science. 2004:306:702-4.

4. Mariani C, Wolters-Arts M. Complex waxes. Plant Cell. 2000;12:1795-8.

5. Sieber P, Schorderet M, Ryser U, Buchala A, Kgolattukudy P, Metraux JP, et al. Transgenic Arabidopsis plants expressing a fungal cutinase show alterations in the structure and properties of the cuticle and postgenital organ fusion. Plant Cell. 2000;12:721-37.

6. Chen XB, Goodwin SM, Boroff VL, Liu X, Jenks MA. Cloning and characterization of the WAX2 gene of Arabidopsis involved in cuticle membrane and wax production. Plant Cell. 2003;15:1170-85.

7. Li LZ, Ma JX, Jiang H, Chen XB. Composition differences of epicuticular and intracuticular wax layers and the relationship between cuticle and plant stress tolerance. Plant Physiol J (Chinese). 2011;47:680-4.

8. Yang J, Ordiz MI, Jaworski GJ, Beachy RN. Induced accumulation of cuticular waxes enhances drought tolerance in Arabidopsis by changes in development of stomata. Plant Physiol Biochem. 2011;49:1448-55.

9. Jetter R, Schaffer S. Chemical composition of the Prunuslaurocerasus leaf surface. Dynamic changes of the epicuticular wax film during leaf development. Plant Physiol. 2001;126:1725-37.

10. Wei CX, Wang JB, Chen YF, Zhou WD, Sun GR. Epicuticular wax of leaf epidermis: a functional structure for salt excretion in a halophyte Puccinellia tenuiflora. Acta Ecol Sin. 2004;24(11):2451-6.

11. Flowers TJ, Flowers SA, Hajibagheri MA, Yeo AR. Salt tolerance in the halophytic wild rice, Porteresia coarctata Tateoka. New Phytol. 1990;114 675-84.

12. Blumwald E, Aharon GS, Apse MP. Sodium transport in plant cells. Biochim Biophys Acta. 2000;1465:140-51.

13. Kim SG, Kim KW, Park EW, Choi D. Silicon-induced cell wall fortification of rice leaves: a possible cellular mechanism of enhanced host resistance to blast. Phytopathology. 2002;92:1095-103.

14. Yoshida S, Ohnishi Y, Kitagishi K. Histochemistry of silicon in rice plant. II. Localization of silicon within rice tissues. Soil Sci Plant Nutr. 1962;8:36-41.

\section{Submit your next manuscript to BioMed Central and take full advantage of:}

- Convenient online submission

- Thorough peer review

- No space constraints or color figure charges

- Immediate publication on acceptance

- Inclusion in PubMed, CAS, Scopus and Google Scholar

- Research which is freely available for redistribution 